\title{
The Study of Cultivating Applied Talents by Local Universities of Tourism-Based on the Concept of Enterprising Education
}

\author{
Yue Wang \\ College of Business Administration, Jilin Engineering Normal University, Changchun, China \\ 51386781@qq.com
}

Keywords: Local Universities; Enterprising Education; Applied talents

\begin{abstract}
According to the actual situation of being badly in need of plenty of professional talents and the transition of local universities' application for the development of tourism in China, from the view of entrepreneurship education, the thesis illustrates the necessity and feasibility of strengthening the cultivation of tourism management talents in local universities, and explores and discusses the research pattern of cultivating the applied talents of tourism.
\end{abstract}

\section{Introduction}

Since China's reform and opening up, the tourism in China is developing rapidly with a driving growth momentum. According to the tourism statistics bulletin from the National Tourism Administration [1], the number of tourists and income in 2015 is presented in Table 1.

Table 12015 national tourist arrivals and tourism income statistics

\begin{tabular}{|c|c|c|c|c|}
\hline Source & $\begin{array}{c}\text { Tourists } \\
\text { (Million passengers) }\end{array}$ & $\begin{array}{c}\text { Growth rate } \\
(\%)\end{array}$ & $\begin{array}{c}\text { Tourism revenue } \\
\text { (One hundred million) }\end{array}$ & $\begin{array}{c}\text { Growth rate } \\
(\%)\end{array}$ \\
\hline Domestic Travel & 41 & 10 & $40000(¥)$ & 12 \\
\hline $\begin{array}{c}\text { Outbound } \\
\text { Tourism }\end{array}$ & 1.2 & 12 & $1045(\$)$ & 16.7 \\
\hline $\begin{array}{c}\text { Inbound } \\
\text { Tourism }\end{array}$ & 1.33 & 4 & $1175.7(\$)$ & 0.6 \\
\hline
\end{tabular}

However, because of the lower threshold of tourism, in the tourism entrepreneurship and employees, there is a large percentage of people who haven't gotten the professional education, which restricts the development of tourism to some extent. So, tourism is badly in need of plenty of well-qualified tourism talents. The tourism management major in the universities has the function and task of cultivating the well-qualified talents in tourism. The influence of inertia of cultivating the job applicants in the industry traditionally restricts the structural adjustment and quality growth of tourism industry. The thesis, from the view of entrepreneurship education, illustrates the necessity and feasibility of strengthening the cultivation of tourism management talents in local universities, and explores and discusses the research pattern of cultivating the applied talents of tourism.

\section{The Necessity and Feasibility of Cultivating the Entrepreneurial Talents}

The Analysis of Necessity of Cultivating the Entrepreneurial Talents. According to the forecast from the World Tourism Organization, China will be the main tourist destination in the world instead of France and America by 2020. Therefore, the tourism industry will contain enormous potentiality and opportunity. At that time, there will be more and more employees in the tourism (Fig. 1). The development of tourism industry would influence the cultivation of tourism talents heavily. The tourism education will face the unprecedented opportunities and challenges. The urgent affairs are to cultivate and establish a well-qualified talents team to accelerate the strategy of developing the tourism 
science and education, and the strategy of reinvigorating tourism through human resource development.

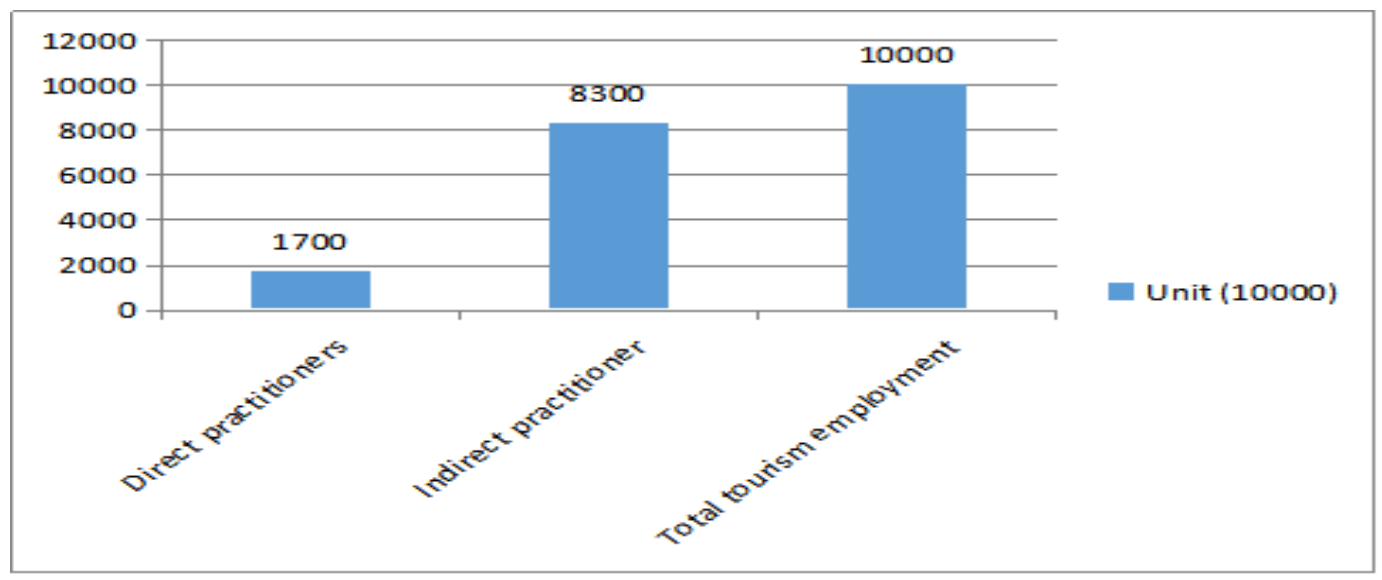

Figure 1. Number of tourism practitioners 2020

By 2015, National Tourism Administration, on June $7^{\text {th }}$, publishes the statistics of tourism educational training in the nationwide in 2014, which illustrates that there are 565 universities admitting the students majoring in tourism management though out the country. There are 1068 colleges to admit the students majoring in tourism management. Among them, there are 147 colleges not only admitting the undergraduate major and specialty. There are also 933 secondary vocational schools in them. According to a research, most of them are the local universities. On one hand, they occupy the favorable factors of rich tourism resource, on the other hand the major or tourism management is regarded as the key major to be established. These local universities cultivate more than one hundred thousand graduates into the tourism industry every year, which only takes $20 \%$ of the employees. Maybe much less in the reality. There are only $30 \%-45 \%$ graduates who work in the tourism industry [2]. The phenomenon of losing the graduates in tourism industry is very serious. According to the relevant data, the graduates in one university in Changchun, are allocated to the hotel. But in the first year, the wastage rate is $50 \%$; after two years, the wastage rate is $80 \%$; after five years, there are only a few graduates who still work in the hotel [3].

At the same time, China's reform and opening up promote the acceleration of transition and development of society construction, which avails formations of all kinds of conditions of tourism development. So the tourism develops powerfully. However, because of the restrictions in systems, the response of universities about the market acquirement is relatively lagging. The pattern of cultivating the tourism talents cannot meet the social needs. There are many problem that the tourism education facing: insufficient investment; unprofessional teachers; disorderly curriculum, lagged content of courses; weak tourism research capacity, low academic research level [4]; unperfected practical teaching system; deficiency of practical teaching facility; lagging of construction of practice base outside school; deficiency of practical teaching faculty [5]; old teaching method, students' weak comprehensive quality, lack of competitive power; light professional consciousness, students' low loyalty [6].

The Analysis of Feasibility of Cultivating the Entrepreneurial Talents. Entrepreneurship is first elaborated in $18^{\text {th }}$ century by Cantillon who is a French economist. Many scholars pay much more closely attention to it, such as Coase (1982), Joseph Schumpeter (1934), Knight (1921). After about two centuries' development, the situation is more and more busy. In November, 1989, the UNESCO hold a international seminar facing the education in $21^{\text {st }}$ century. The seminar emphases that educations should cultivate the students' spirit and capacity of exploiting the career, which is enterprising education. In 1999, the UNESCO published an article "Higher Education in $21^{\text {st }}$ Century: the World Declaration of Expectation and Action" to put forward that the elementary object of higher education is to cultivate the skills and spirit of entrepreneurship. 
Enterprising education has been organized in China for more than 20 years. There are so many domestic scholars paying much attention about the enterprising education in universities, such as Zhang Jian (2003), Chen Zhenhong (2004), Zhang Yuli (2004). "Action Plan for Invigorating Education Facing the $20^{\text {th }}$ Century", formulated by Ministry of Education formulateon $24^{\text {th }}$ December, 1998 and endorsed by state department, emphasized we should strengthen the enterprising education of teachers and students, and encourage to establish high and new technology enterprise independently. On this, the Chinese universities act positively and set off a huge wave of development of enterprising education in universities. The Ministry of Education established a steering committee of enterprising education in universities in 2009. In 2010, they issued the "Opinions the giving great impetus to enterprising education in universities and self-employed by the university students", which reinforces the instruction and service for the students starting their own business. "Introducing of Outline of National Mid and Long Term Reforming and Development of Education" indicates that we need to give a big push to the work of enterprising education in the universities. Then the innovative enterprising education steps in a period of comprehensively promotion, in the instruction of the Ministry of Education, which forms a new driving pattern of innovative enterprising education, base construction, policy support and enterprising service.

Our country proposes that entrepreneurship can promote the employment. It also proposes that the universities should carry on the enterprising education with the whole proceeding, the whole member, professionalization, informatization. The local universities, as the dominant force of cultivating tourism professional talents, need to regard the development of tourism industry as the opportunity, regard necessity of tourism talents as the purpose. They also need to let the concept of enterprising education running through the educational theory and educational thought of tourism talents. The universities should combine the experience and achievement of cultivating the tourism talents within the more than 20 years, to change the cultivated pattern which pays attention to integrity of theory and knowledge, to pay attention to the promoted capacity of applicability and practicalness, to complete the teachers with excellent content and allocation to the curriculum system of theory and practice, to implement the eclectic instructional mode. Thereby, the pattern of educating and cultivating the tourism talents can be established.

\section{The Study of Local Universities Cultivate Applied Talents of Tourism Based on the Concept of Enterprising Education}

Transform the Cultivated Theory and Confirm the Goal of the Tourism Talents Orientation. According to the forecast from the World Tourism Organization, China will be the main tourist The major of tourism management has a very strong practicalness, which is related to catering industry, travel agency management, hotel industry, business travel, exhibition and conference management, tourism planning and so on [7]. Based on the concept of cultivating tourism talents, educational thought, which depends on the capacity, is implemented very well. In the aspect of goal of cultivation, the entrepreneurial talents majoring in tourism management pay much attention on the knowledge, quality and capacity. Knowledge structure highlights the basic theoretical knowledge of tourism management, tourism planning and service, meanwhile, and the policies, laws and regulations relating to tourism. In the aspect of ability structure, the the tourism management major cultivates the talents with professional ability, innovation and enterprise capability, executive capacity, insight of market recognition and teamwork. In the aspect of quality, they need the talents have the capability of adapting himself and compressive resistance when the talents face the difficulty and setback. The tourism management major are also prone to the talents with healthy body, loyalty, entrepreneur spirit, social responsibility and adapting in integrating the social resources.

On the educational concept, the teaching centered position should be confirm, which is used to cultivating the enterprise consciousness and entrepreneurial ability by the local universities. The great education concept of openness, systematicness and perspectiveness. The tourism management needs to change the educational environment of restricting in the major, course, books and schools. It also 
transforms the passive relationship between teachers and students. Then teaching pattern of depending on teachers need to be changed to the new teaching pattern of depending on active students, dynamic teachers and interactive relationship between teachers and students. All the things should be developed centering on the students.

Reset the Curriculum System and Intensify the Correspondence between the Major and the entrepreneurial Education. At present, the education of the tourism management major is still based on the theoretical knowledge, and neglects the specialty literacy and the specialized skills. Even more, the theoretical knowledge is instead of the practical operation, which does not represent the main position of students. The proportion of curriculum system is approximately: there are $15 \%$ general courses; there are $30 \%$ elementary courses; there are $40 \%$ professional courses; there are only $15 \%$ internship courses. The pattern cannot cultivate the tourism talents to reach the standards that the society needs.

Using the experience of other countries for reference, we need to adopt the principles of reverse thinking to accumulate the study [8]. We also need to update the curriculum. We should set up the principle line of cultivating the professional application ability and professional quality to let the students' career goal come true. Besides the specialized courses, the universities should pioneered the elective system, including the curriculum system designed for the students' development direction and necessity. Through the study of the curriculum system, students can know more about this industry and master the more specialized knowledge.

Strengthen the Teaching Implementation and Highlight the Teaching Staff and Practical Teaching. Entrepreneurial education is the important content of cultivating the entrepreneurial talents [9]. Teaching implementation is the centered work in cultivating talents. Teachers are the main part of teaching implementation. At present, the geography teachers and history teachers take a part-time job to be the teachers in the tourism management in the local universities. In recent years, the teachers are the graduates from the universities who are lack of organizing the tourism practice. Besides that, the teachers don't have clear consciousness about enterprising education. The most usual ways to enterprising educations are carrying on the competition of designing entrepreneurship, special lecture. Most of them are the armchair strategist. The proportion of experienced training, such as simulating entrepreneurship and project training, is very small. So the result of entrepreneurial education is not very obvious. Then to strengthen the environment of implementation of teaching, the two big problems which are entrepreneurial teaching staff of tourism management and teaching forms and methods.

From the perspective of teaching staff construction, the universities should pay attention to the practices guidance who has worked in the travelling department when the universities recruit new teachers. The universities should also arrange their teachers to the tourist enterprise to experience. On one hand, according to employ the successful entrepreneurs in the tourism industry or other professors in different industries can explore more rich practice of innovation and entrepreneurship actively. On the other hand, the universities should guide the teachers working in the major of tourism management to study the theory and case of enterprising education, encourage the teachers to take their part-time job in the tourism industry or join in the training of enterprising education. Then the pattern of the knowledgeable and practical teachers can be stabilized [10].

From the perspective of teaching forms and methods, the universities should attach importance to process of enterprising education to achieve the cultivation of experience of entrepreneurial practice and entrepreneurial capacity. On one hand, satisfying the students can be the biggest starting point for the education class. The teaching forms can be speech by the entrepreneurs, lecture of visiting professor, case study, visited internship, stimulating training, teaching online and so on. On the other hand, the universities should set up a scaffold for the students majoring in the tourism management, cooperate actively between school and enterprise, introduce the diversified social entrepreneurial resources into the universities, to provide the real and simulated opportunities for training the entrepreneurial practice.

Integrate Teaching Resource and Promote Local Development and Resource Sharing. Recently, although there is a tighter relationship between the local universities and government, 
especially for the tourism management. But the situation is still short of power, with low degree of binding and unobvious result. Cultivating the entrepreneurial talents in the tourism management in the universities cannot work well without the strong and powerful external environment. Integrating the resources of government, entrepreneur, scholars, other universities and social entrepreneurship institution, can urge the entrepreneurial project with formation and industrialization, to let the integrative development of resources sharing and industry-university-research cooperation come true.

The local universities cultivating the entrepreneurial talents in tourism management should pay attention to integrate educational resources. On one hand, the local universities should actively seek for the support of government and the social participation. They should combine the enterprising education of students majoring tourism management with the local economic development, set up the special fund in tourism industry, complete the universities students' innovation undertaking, broaden the entrepreneurial opportunities, support the entrepreneurial growth. At the same time, the universities should build the domestic exchange platform, be in line with international academic to let the integrative development of resources sharing and industry-university-research cooperation come true. On the other hand, the universities should strengthen the cooperation with other institutions of enterprising education in the society, with other universities and with the other majors inner the university. They can promote the development of the enterprising education and enterprising research together. Then, they can share the limited and scarce resources of enterprising education and experience roundly.

\section{Conclusion}

For the past years, with the booming development of tourism, the requirement of tourism talents that the society asks for is higher and higher. Well-qualified graduates majoring in tourism would strongly promote the development of the entire industry. The local universities cultivate the tourism talents basing on the application and innovation. Enterprising education starts late in China. Cultivation conception, teaching conditions, teachers and ways of evaluating are far more behind the developed country. Breaking the traditional teaching pattern and integrating all kinds of teaching resources need more time and a long process. Therefore, cultivating the applied talents in tourism is still a challengeable task, and cultivating the high-level talents in tourism is the mission for the tourism management in the universities.

\section{References}

[1] Information on http://www.askci.com/news/chanye/2016.01/13/161853tpx1.shtml.

[2] P.P. Chen, S.P. Wu: Technology Consulting Herald, Vol.4 (2007), No.22, p.249-250.

[3] Y. Liu: Liaoing Provincial College of Communications, Vol.11 (2009) No.3, p.70-72.

[4] Q.H. Chen, J.H. Zhang: Journal of Fujian Agriculture and Forestry University (Philosophy and Social Science Edition), Vol.8 (2008) No.3, p.71-74.

[5] Y.Y. Lin: Market Weekly, Vol.10 (2011) No.2, p.119-120.

[6] Y. Liu: Journal of Liaoning Privincial College of Communications, Vol.11 (2009) No.3, p.70-72.

[7] J.P. Stephen: Tourism Management (Florence Production Ltd, Routledge 2015).

[8] Y. Qiu: Modern Communication, Vol.17 (2010) No.1, p.58-62.

[9] H. Mei, Z. Zhan, S.W. Patrick: Applied Economics, Vol.48 (2016) No.13, p.1240-1254.

[10] N.S. Richard, L. Ruhanen, N. M. Breakey: Current Issues in Tourism, Vol.19 (2016) No.6, p.513-527. 